\title{
Comparative study of $\mathrm{La}_{0.6} \mathrm{Sr}_{0.4} \mathrm{Co}_{0.2} \mathrm{Fe}_{0.8} \mathrm{O}_{3}, \mathrm{Ba}_{0.5} \mathrm{Sr}_{0.5} \mathrm{Co}_{0.2} \mathrm{Fe}_{0.8} \mathrm{O}_{3}$ and
}

\section{$\mathrm{Sm}_{0.5} \mathrm{Sr}_{0.5} \mathrm{Co}_{0.2} \mathrm{Fe}_{0.8} \mathrm{O}_{3}$ cathodes and the effect of $\mathrm{Sm}_{0.2} \mathrm{Ce}_{0.8} \mathrm{O}_{2}$ block layer in solid oxide fuel cells}

\author{
Fengyu Shen and Kathy Lu*
}

Department of Materials Science and Engineering, Virginia Tech, VA 24061, USA

\begin{abstract}
*Corresponding author: 211B Holden Hall, Virginia Tech, Blacksburg, VA 24061, USA. Email: klu@vt.edu; Phone: 540-231-3225; Fax: 540-231-8919
\end{abstract}

\begin{abstract}
In the pursuit for solid oxide fuel cell (SOFC) cathode materials which can perform better at $800^{\circ} \mathrm{C}$, perovskite structure materials $\mathrm{La}_{0.6} \mathrm{Sr}_{0.4} \mathrm{Co}_{0.2} \mathrm{Fe}_{0.8} \mathrm{O}_{3} \quad(\mathrm{LSCF}), \quad \mathrm{Ba}_{0.5} \mathrm{Sr}_{0.5} \mathrm{Co}_{0.2} \mathrm{Fe}_{0.8} \mathrm{O}_{3}$ (BSCF), and $\mathrm{Sm}_{0.5} \mathrm{Sr}_{0.5} \mathrm{Co}_{0.2} \mathrm{Fe}_{0.8} \mathrm{O}_{3}$ (SSCF) are studied. Their electrochemical performance as the cathodes is compared by electrochemical impedance spectroscopy (EIS) at $800^{\circ} \mathrm{C}$ for $100 \mathrm{hrs}$ through an AISI 441 interconnect/cathode/yttria-stabilized zirconia (YSZ) electrolyte half-cell structure. SSCF cathode has the smallest polarization resistance and is the most desired cathode at $800^{\circ} \mathrm{C}$ while $\mathrm{BSCF}$ cathode has the largest one. $\mathrm{SrCrO}_{4}$ phase forms on the LSCF and SSCF cathodes near the interconnect, but not on the BSCF cathode. With the spin coating of $\sim 3 \mu \mathrm{m}$ thick $\mathrm{Sm}_{0.2} \mathrm{Ce}_{0.8} \mathrm{O}_{2}$ (SDC) block layer on the YSZ electrolyte, the polarization resistances of the three cathode materials all decrease. The SDC layer can effectively decrease the mismatch of the thermal expansion coefficients (TECs) between BSCF and YSZ.
\end{abstract}

Keywords: LSCF; BSCF; SSCF; SDC; Block layer; Solid oxide fuel cell 


\section{Introduction}

One of the main hurdles in the development of solid oxide fuel cells (SOFCs) is the large resistance for the oxygen reduction reaction at the triple-phase boundary (TPB) between electrolyte, cathode, and gas [1-3]. For SOFCs with low ionic conductivity cathodes, the oxygen reduction reaction mainly happens at the TPBs [4-6]. But for mixed ionic-electronic conductors, which are promising cathode materials, the oxygen reduction reaction is not just limited to the TPB sites but can be extended to two-phase boundary sites between the cathode and gas [7-9]. They also have much higher oxygen ionic conductivity than the conventional $(\mathrm{LaSr}) \mathrm{MnO}_{3}$ cathode material $[10,11]$.

Iron-cobalt-based $\mathrm{ABO}_{3}$ cubic perovskite-structured oxides have attracted much attention as a promising cathode material for SOFCs because of their high electronic conductivity and high oxygen reduction activity based on disorder-free oxygen ion migration mechanism [12]. Among various compositions, $\mathrm{La}_{0.6} \mathrm{Sr}_{0.4} \mathrm{Co}_{0.2} \mathrm{Fe}_{0.8} \mathrm{O}_{3}$ (LSCF) has received significant attention due to its remarkable electrochemical properties. Electronic conductivity of LSCF is as high as $269 \mathrm{~S} / \mathrm{cm}$ at $800^{\circ} \mathrm{C}$ with ionic conductivity at $5.8 \times 10^{-2} \mathrm{~S} / \mathrm{cm}[13]$. La and $\mathrm{Sr}$ occupy the A-sites and Co and Fe occupy the B-sites. Park et al. reported the total resistance of $0.55 \Omega \cdot \mathrm{cm}^{2}, 0.86 \Omega \cdot \mathrm{cm}^{2}$, and $1.56 \Omega \cdot \mathrm{cm}^{2}$ at $730^{\circ} \mathrm{C}, 680^{\circ} \mathrm{C}$, and $630^{\circ} \mathrm{C}$ respectively for a Ni-YSZ/YSZ/GDC/LSCF cell [14]. $\mathrm{Ba}_{0.5} \mathrm{Sr}_{0.5} \mathrm{Co}_{0.2} \mathrm{Fe}_{0.8} \mathrm{O}_{3}$ (BSCF) is another promising cathode material with electronic conductivity as $25 \mathrm{~S} / \mathrm{cm}$ at $800^{\circ} \mathrm{C}$ [15]. Its calculated ionic conductivity is as high as $0.96 \mathrm{~S} / \mathrm{cm}$ at $800^{\circ} \mathrm{C}$ [16]. Compared with LSCF, BSCF has Ba substituting La at A-sites and was reported as a novel cathode material with excellent performance at temperatures even lower than $600^{\circ} \mathrm{C}$. Shao et al. obtained low area specific resistance of $0.055-0.071 \Omega \cdot \mathrm{cm}^{2}$ at $600^{\circ} \mathrm{C}$ and $0.51-0.60 \Omega \cdot \mathrm{cm}^{2}$ at 
$500^{\circ} \mathrm{C}$ with $\mathrm{BSCF}$ as the cathode and SDC as the electrolyte [2, 17]. $\mathrm{Sm}_{0.5} \mathrm{Sr}_{0.5} \mathrm{Co}_{0.2} \mathrm{Fe}_{0.8} \mathrm{O}_{3}$ (SSCF) is also a cathode material, obtained through Sm substituting Ba in BSCF. Its electrical conductivity is higher than $100 \mathrm{~S} / \mathrm{cm}$ at $800^{\circ} \mathrm{C}$ [18]. However, this material has not gained much attention $[19,20]$. Lv et al. showed that the polarization resistance of SSCF is $0.17 \Omega \cdot \mathrm{cm}^{2}$ at $800^{\circ} \mathrm{C}$ with $\mathrm{La}_{0.8} \mathrm{Sr}_{0.2} \mathrm{Ga}_{0.8} \mathrm{Mg}_{0.2} \mathrm{O}_{3}$ as the electrolyte [18].

Several possible degradation mechanisms for cathode materials have been proposed, such as phase transformation [21], coarsening of particles [22], chromium poisoning from the interconnect [23], and reaction between the cathode and the electrolyte [24]. Solid state reaction between the cathode and the YSZ electrolyte due to the elemental diffusion is widely accepted as the reason for the instability of perovskite cathode materials. The introduction of a SDC block layer can separate the cathode and the YSZ electrolyte and prevent reactions during both the cell fabrication and the cell operation. The ionic conductivity of SDC is as high as $8.4 \times 10^{-2} \mathrm{~S} / \mathrm{cm}$ around $800^{\circ} \mathrm{C}$, which is much higher than that of YSZ [25]. Moreover, the thermal expansion coefficient (TEC) of SDC is $\sim 12.2 \times 10^{-6} \mathrm{~K}^{-1}$ [26], which can decrease the difference in the TECs between the YSZ electrolyte and the cathodes.

Although LSCF, BSCF, and SSCF as cathode materials have been reported separately, they have not been comparatively studied at the same conditions. The effect of the SDC block layer on the interaction of the LSCF, BSCF, and SSCF cathodes with the YSZ electrolyte has not been systematically evaluated. In this study, we have synthesized LSCF, BSCF, and SSCF cathodes with the same method and measured their electrochemical performance through $100 \mathrm{hrs}$ of thermal treatment under the same conditions. The microstructures of the cathode/interconnect interfaces and the cathodes themselves are examined. The elemental concentrations are quantified. In addition, the electrochemical performance of half-cells with and without the SDC 
block layer between the cathodes and the electrolyte has been compared. Based on these efforts, the enhanced electrochemical performance for the cathodes is explained.

\section{Experimental procedures}

\subsection{Chemicals}

$\mathrm{La}\left(\mathrm{NO}_{3}\right)_{3} \cdot 6 \mathrm{H}_{2} \mathrm{O}, \mathrm{Sr}\left(\mathrm{NO}_{3}\right)_{2}, \mathrm{Co}\left(\mathrm{NO}_{3}\right)_{2} \cdot 6 \mathrm{H}_{2} \mathrm{O}, \mathrm{Fe}\left(\mathrm{NO}_{3}\right)_{3} \cdot 9 \mathrm{H}_{2} \mathrm{O}, \mathrm{Ba}\left(\mathrm{NO}_{3}\right)_{2}, \mathrm{Sm}\left(\mathrm{NO}_{3}\right)_{3} \cdot 6 \mathrm{H}_{2} \mathrm{O}$ ethylenediaminetetraacetic acid, citric acid, $\mathrm{NH}_{4} \mathrm{NO}_{3}$, sucrose, and $\mathrm{NH}_{3} \cdot \mathrm{H}_{2} \mathrm{O}$ were purchased from Alfa Aesar. $\alpha$-terpineol as solvent was purchased from Sigma-Aldrich. Microcrystalline cellulose as a pore forming agent was purchased from Gardena. Ethyl cellulose as a binder was purchased from Acros Organics. YSZ was purchased from Nextech Materials. AISI 441 was produced by ATI Allegheny Ludlum Corporation. Polyacrylic acid (PAA) as the dispersant for making SDC suspension was purchased from Thermo Fisher Scientific.

\subsection{Synthesis of LSCF, BSCF, SSCF, and SDC powders}

Perovskite LSCF powder was synthesized by a combustion method. The molar ratio of $\mathrm{La}\left(\mathrm{NO}_{3}\right)_{3} \cdot 6 \mathrm{H}_{2} \mathrm{O}, \mathrm{Sr}\left(\mathrm{NO}_{3}\right)_{2}, \mathrm{Co}\left(\mathrm{NO}_{3}\right)_{2} \cdot 6 \mathrm{H}_{2} \mathrm{O}$, and $\mathrm{Fe}\left(\mathrm{NO}_{3}\right)_{3} \cdot 9 \mathrm{H}_{2} \mathrm{O}$ was $6: 4: 2: 8$ and the molar ratio of metal ions, ethylenediaminetetraacetic acid (EDTA), citric acid, ammonium nitrate, sucrose was $2: 1: 2: 10: 0.75$. In the first step, the metal nitrates were dissolved in distilled water in a beaker; EDTA, citric acid, ammonium nitrate, and sucrose were added. The $\mathrm{pH}$ value was adjusted by ammonium hydroxide to 6 to completely dissolve EDTA. With the usage of a mesh on the top of a beaker the solution was placed in a pre-heated furnace at $450^{\circ} \mathrm{C}$. After 10 minutes the combustion process was completed and the beaker was taken out to cool down. The combusted 
powder was calcined at $900^{\circ} \mathrm{C}$ for $2 \mathrm{hrs}$ and milled before use. The reaction equation was as follows [27]:

$0.6 \mathrm{La}\left(\mathrm{NO}_{3}\right)_{3}+0.4 \mathrm{Sr}\left(\mathrm{NO}_{3}\right)_{2}+0.2 \mathrm{Co}\left(\mathrm{NO}_{3}\right)_{2}+0.8 \mathrm{Fe}\left(\mathrm{NO}_{3}\right)_{3}+\mathrm{C}_{10} \mathrm{H}_{16} \mathrm{~N}_{2} \mathrm{O}_{8}+2 \mathrm{C}_{6} \mathrm{H}_{8} \mathrm{O}_{7}+$ $10 \mathrm{NH}_{4} \mathrm{NO}_{3}+0.7 \mathrm{C}_{11} \mathrm{H}_{22} \mathrm{O}_{11}+14.15 \mathrm{O}_{2} \rightarrow \mathrm{La}_{0.6} \mathrm{Sr}_{0.4} \mathrm{Co}_{0.2} \mathrm{Fe}_{0.8} \mathrm{O}_{3}+13.7 \mathrm{~N}_{2}+44.25 \mathrm{H}_{2} \mathrm{O}+$ $30.25 \mathrm{CO}_{2}$

For the synthesis of BSCF and SSCF powders, the above procedure was followed with the exception of the raw materials and molar ratios of metal ions. $\mathrm{La}\left(\mathrm{NO}_{3}\right)_{3} \cdot 6 \mathrm{H}_{2} \mathrm{O}$ was substituted by $\mathrm{Ba}\left(\mathrm{NO}_{3}\right)_{2}$ and $\mathrm{Sm}\left(\mathrm{NO}_{3}\right)_{3} \cdot 6 \mathrm{H}_{2} \mathrm{O}$ for BSCF and SSCF respectively.

SDC powder was synthesized by a sol-gel method. First, stoichiometric amounts of $\mathrm{Sm}\left(\mathrm{NO}_{3}\right)_{3} \cdot 6 \mathrm{H}_{2} \mathrm{O}$ and $\mathrm{Ce}\left(\mathrm{NO}_{3}\right)_{3} \cdot 6 \mathrm{H}_{2} \mathrm{O}$ (according to the molecular composition of the oxides) were mixed into a water solution. EDTA and citric acid were used as the chelating agents. The molar ratio of total metal ions, EDTA, and citric acid was 1:1:2. The ammonium hydroxide was used to adjust the $\mathrm{pH}$ value of the solution to 6 . Water was evaporated from the solution while stirring at $80^{\circ} \mathrm{C}$, creating transparent gels that were kept at $200^{\circ} \mathrm{C}$ for $2 \mathrm{hrs}$ and calcined at $800^{\circ} \mathrm{C}$ for $4 \mathrm{hrs}$. The SDC powder was milled before use.

\subsection{Deposition of SDC block layer}

The SDC block layer was deposited by spin coating. Before spin coating, a SDC suspension was prepared. $\mathrm{NH}_{3} \cdot \mathrm{H}_{2} \mathrm{O}$ was used as the solvent with $\mathrm{pH}$ at 11 . The solid content of SDC was 10 vol\%. $6 \mathrm{wt} \%$ of PAA was added as a dispersant. Then the suspension was obtained after vibratory milling for $1 \mathrm{hr}$. The spin coating process was set at $500 \mathrm{rpm} / \mathrm{s}$ for $5 \mathrm{~s}$ then at 3000 $\mathrm{rpm} / \mathrm{s}$ for $60 \mathrm{~s}$. After the spin coated layer dried at room temperature, it was calcined at $1200^{\circ} \mathrm{C}$ 
for $4 \mathrm{hrs}$ with a heating and cooling rate of $2^{\circ} \mathrm{C} / \mathrm{min}$. The second SDC layer was deposited with the same spin coating and calcination process.

\subsection{Assembly of AISI 441/cathode/YSZ and AISI 441/cathode/SDC/YSZ structures}

The cathode material (56.8 wt\%) was mixed and ball-milled with microcrystalline cellulose, ethyl cellulose, and $\alpha$-terpineol for $1 \mathrm{hr}$ to make pastes for screen printing. The prepared pastes were screen printed on $8 \mathrm{~mol} \%$ YSZ substrates, using a \#330 mesh. The screen printed pastes were square-like with $\sim 0.5 \mathrm{~cm}^{2}$ area. The cathode/YSZ structure was kept at $200^{\circ} \mathrm{C}$ for $3 \mathrm{hrs}$ and at $400^{\circ} \mathrm{C}$ for $1 \mathrm{hr}$ to partially remove the binder and solvent and was then kept at $950^{\circ} \mathrm{C}$ for $2 \mathrm{hrs}$ to complete binder removal and bond with YSZ; a heating and cooling rate of $1^{\circ} \mathrm{C} \min ^{-1}$ was used. The same process was used to screen print the cathodes on the SDC coated YSZ electrolyte.

AISI 441 ferritic steel pieces were used as the interconnect material and were cut into rectangular substrates (area: $10 \times 10 \mathrm{~mm}^{2}$ ). In order to remove the oxidized layer and obtain a scratch free flat surface, the steel pieces were polished to optical finish, and ultrasonically cleaned with water and ethanol. The polished AISI 441 alloy piece was placed on the cathode side and the configuration was shown in our previous paper [28].

\subsection{Thermal treatment under current load}

In order to investigate the electrochemical behaviors of the LSCF, BSCF, and SSCF cathodes with and without the SDC block layer, the AISI 441/cathode/YSZ half cells were heated to $800^{\circ} \mathrm{C}$, using a tube furnace $(1730-20 \mathrm{HT}$ Furnace, CM Furnace Inc. Bloomfield, NJ) in dry air environment. Afterwards, the hall-cells were cathodically polarized using a potentiostat (VersaSTAT 3, Princeton Applied Research, Oak Ridge, TN). A platinum mesh was placed in- 
between the porous cathode layer and the AISI 441 interconnect to optimize the current distribution, and the electrodes were connected by Pt wires along with a Pd paste. The working electrode was positioned at the center of the YSZ electrolyte with about the same area as the cathode. The reference electrode was painted as a ring around the working electrode. The counter electrode was positioned at the center of the interconnect and the reference electrode was painted on the edge. The EIS testing program used was a multi-loop process with the frequency from 100 $\mathrm{kHz}$ to $0.025 \mathrm{~Hz}$. The amplitude was $10 \mathrm{mV}$. After that, a current density of $200 \mathrm{~mA} / \mathrm{cm}^{2}$ was applied to mimic the working condition of an actual fuel cell. EIS data were recorded every $2 \mathrm{hrs}$ during the thermal treatment.

\subsection{Characterization and performance testing}

X-ray diffraction (XRD, X'Pert PRO diffractometer, PANalytical B.V., EA Almelo, The Netherlands) analysis was employed to characterize the crystallinity of the synthesized powders. The microstructures of the cathodes before and after the thermal treatment were examined by a field-emission scanning electron microscope (FESEM, LEO (Zeiss) 1550) and an environmental scanning electron microscope (ESEM, FEI Quanta 600 FEG), with a carbon layer coating applied before imaging. The energy dispersive X-ray spectroscopy module (EDS, BrukerAXS, MicroanalysisGmbh, Berlin, Germany) attached to the ESEM was used to line scan the cross sections of the cathodes and the electrolyte after $100 \mathrm{hrs}$ of the thermal treatment.

\section{Discussion}

\subsection{Microstructures}


Fig. 1(a) shows the XRD patterns of the synthesized LSCF, BSCF, and SSCF powders. They have the same crystal structure, showing pure perovskite phase. In order to show the differences of the diffracted peaks in these three materials, the main (110) peaks are enlarged and shown in Fig. 1(b). They are located at $32.7^{\circ}$ for LSCF, $32^{\circ}$ for BSCF, and $33^{\circ}$ for SSCF, which demonstrates the peak shift from right to left for SSCF, LSCF, and BSCF. This means replacing $\mathrm{La}$ with $\mathrm{Ba}$ increases the lattice constant of the perovskite crystal structure; while replacing $\mathrm{La}$ with Sm decreases the lattice constant of the perovskite crystal structure. The (110) peak shift is due to the ionic radius difference from $\mathrm{La}^{3+}(1.36 \AA), \mathrm{Ba}^{2+}(1.61 \AA)$, and $\mathrm{Sm}^{3+}(1.24 \AA)$ with the relationship of $\mathrm{Ba}^{2+}>\mathrm{La}^{3+}>\mathrm{Sm}^{3+}$. The lattice parameters of the synthesized perovskite LSCF, BSCF, and SSCF are calculated to be $3.8666 \AA, 3.9495 \AA$, and $3.8410 \AA$, respectively, which are smaller than the reported values, $3.8973 \AA$ [29], $3.9554 \AA$ [14], and $3.8547 \AA$ [18] but are fairly close.

The top surface microstructure and the cross section of the SDC block layer are shown in Fig. 2. According to the top surface shown in Fig. 2(a), the SDC layer is not fully dense, so two layers were spin coated to increase its thickness. The particle size of the SDC is about $40 \mathrm{~nm}$ and the pore size shown in the inset is also about $40 \mathrm{~nm}$. The total thickness of the SDC block layer is about $3 \mu \mathrm{m}$ (Fig. 2(b)).

The microstructures of the cathode/interconnect interface after $100 \mathrm{hrs}$ of the thermal treatment at $800^{\circ} \mathrm{C}$ are shown in Figs. 3(a)-(c). As expected, all the electrode layers are porous. For the LSCF cathode shown in Fig. 3(a), some larger particles appear after $100 \mathrm{hrs}$ of the thermal treatment, while the other particles remain the same size as the initial particles. The large particle size is over $1 \mu \mathrm{m}$. For the BSCF cathode shown in Fig. 3(b), particles remain the same size as that before the thermal treatment, which is about $700 \mathrm{~nm}$. However, the particles neck 
together because of the diffusion in the contact regions during the EIS test. For the SSCF cathode shown in Fig. 3(c), the microstructure change is similar to that of the LSCF cathode. Larger particles and smaller particles co-exist and the large particle size is even as large as $2 \mu \mathrm{m}$.

Through the comparison of the microstructures of the cathode/interconnect interface after $100 \mathrm{hrs}$ of the thermal treatment at $800^{\circ} \mathrm{C}$, it is clear that the $\mathrm{BSCF}$ particles are more resistant to large particle formation than the LSCF and SSCF particles. The electrochemical performance of these cathodes would be affected by the changes in their microstructures, which will be discussed in Section 3.2. In order to distinguish the elemental changes from small particles to large particles, EDS is used to detect the relative elemental concentrations. The detected locations are shown in Figs. 3(a)-(c) and the relative elemental concentrations are shown in Table 1. For the LSCF and SSCF cathodes, the relative $\mathrm{Sr}$ and $\mathrm{Cr}$ concentrations from larger particles ( 1 and 5) are higher than those from smaller particles (2 and 6). The difference is especially obvious for $\mathrm{Cr}$. This means that $\mathrm{Sr}$ and $\mathrm{Cr}$ are enriched in the larger particles. Consistent with our and others' earlier observations [30-32], $\mathrm{SrCrO}_{4}$ formation is common in $\mathrm{Sr}-$ containing cathodes and they preferentially distribute at the cathode/interconnect interface to compromise the cell performance. Surprisingly, for the BSCF cathode, because no coarsened particles are found at the cathode/interconnect interface, there is not much elemental concentration difference for the two random spots 3 and 4 . This means that the BSCF cathode is resistant to $\mathrm{Cr}$ poisoning. It is possible that $\mathrm{Ba}^{2+}$ has large enough atomic radius $(1.61 \AA)$ at the $\mathrm{A}$ sites in the BSCF perovskite structure, which can effectively accommodate the $\mathrm{Sr}^{2+}$ ions and prevent the reaction of $\mathrm{Sr}^{2+}$ with the poisonous $\mathrm{CrO}_{3}$ vapor in the dry air environment used for the study. 
The microstructures of the LSCF, BSCF, and SSCF cathode bulks after $100 \mathrm{hrs}$ of the thermal treatment are shown in Figs. 3(d)-(f). There are few coarsened particles found. The particle sizes of LSCF, BSCF, and SSCF are about $60 \mathrm{~nm}, 700 \mathrm{~nm}$, and $150 \mathrm{~nm}$ respectively, which are almost the same as the initial particle size. The microstructures of LSCF and SSCF are similar but considerably different from BSCF. This can be explained as follows. La and Sm are lanthanide and have very similar physical and chemical properties, such as close ionic radii (1.36 $\AA$ and $1.24 \AA$, respectively). Ba is not lanthanide and has much larger ionic radius (1.61 $\AA$ ). Generally, smaller particles mean larger specific surface area and more two phase boundaries between the cathode and the gas phase. This is to say, as mixed ionic-electronic conductors for LSCF, BSCF, and SSCF, smaller particle size should improve oxygen adsorption area on the cathode. After $100 \mathrm{hrs}$ of the thermal treatment, the particle sizes almost remain unchanged. This means that only some particles at the cathode/interconnect interface have grown for LSCF and SSCF.

\subsection{Electrochemical behaviors}

In order to understand the fundamental process in different half-cells and correlate the electrochemical behaviors with the cathode evolution, equivalent circuit $\mathrm{R}_{\Omega}\left(\mathrm{R}_{\mathrm{H}} C P E_{H}\right)\left(\mathrm{R}_{\mathrm{L}} C P E_{L}\right)$, shown in our previous work [33], has been used to fit the EIS spectra and obtain deconvoluted arcs at different frequencies. In the circuit, $\mathrm{R}_{\Omega}$ is the ohmic resistance from the cathode, the Pt wires, the Pd paste, the contact between the interconnect and the cathode, and the electrolyte; however, the major contribution and especially the changes are from the cathode. $\mathrm{R}_{\mathrm{H}}$ and $\mathrm{R}_{\mathrm{L}}$ refer to the polarization resistances at high and low frequencies, while $\mathrm{CPE}_{\mathrm{H}}$ and $\mathrm{CPE}_{\mathrm{L}}$ are constant phase elements corresponding to each frequency range. The high frequency resistance 
$\mathrm{R}_{\mathrm{H}}$ corresponds to $\mathrm{O}^{2-}$ incorporation into the electrode and its transport in the cathode; and the low frequency resistance $R_{L}$ in the impedance spectra is attributed to oxygen adsorption and dissociation as well as its surface diffusion [34].

Figs. 4(a)-(c) shows the $\mathrm{R}_{\Omega}, \mathrm{R}_{H}$, and $\mathrm{R}_{\mathrm{L}}$ changes for the half-cells with LSCF, BSCF, and SSCF as the cathode without the SDC block layer respectively. For the LSCF cathode (Fig. 4(a)), the $R_{\Omega}$ value increases slightly with the thermal treatment time, from $0.9 \Omega \cdot \mathrm{cm}^{2}$ to $1.3 \Omega \cdot \mathrm{cm}^{2}$. The $\mathrm{R}_{\mathrm{H}}$ value first increases slightly from $0.8 \Omega \cdot \mathrm{cm}^{2}$ to $1.2 \Omega \cdot \mathrm{cm}^{2}$ after $20 \mathrm{hrs}$ of the thermal treatment, then decreases to $0.1 \Omega \cdot \mathrm{cm}^{2}$ at the end of the thermal treatment. Additionally, the $\mathrm{R}_{\mathrm{L}}$ value increases drastically, from $1.3 \Omega \cdot \mathrm{cm}^{2}$ to $4.5 \Omega \cdot \mathrm{cm}^{2}$. For the BSCF cathode (Fig. 4(b)), the value of $\mathrm{R}_{\Omega}$ is high at $3.1 \Omega \cdot \mathrm{cm}^{2}$ and decreases gradually to $2.5 \Omega \cdot \mathrm{cm}^{2}$ after $100 \mathrm{hrs}$ of the thermal treatment. The value of $\mathrm{R}_{\mathrm{H}}$ first decreases quickly from $1.4 \Omega \cdot \mathrm{cm}^{2}$ to $0.7 \Omega \cdot \mathrm{cm}^{2}$ after 20 hrs of the thermal treatment, then almost stays flat at $0.7 \Omega \cdot \mathrm{cm}^{2}$. In addition, the value of $\mathrm{R}_{\mathrm{L}}$ increases from $2.5 \Omega \cdot \mathrm{cm}^{2}$ to $4.4 \Omega \cdot \mathrm{cm}^{2}$ after $20 \mathrm{hrs}$ of the thermal treatment, then increases gradually to $4.9 \Omega \cdot \mathrm{cm}^{2}$ after $100 \mathrm{hrs}$ of the thermal treatment. For the SSCF cathode (Fig. 4(c)), the value of $\mathrm{R}_{\Omega}$ decreases from $3.5 \Omega \cdot \mathrm{cm}^{2}$ to $2.0 \Omega \cdot \mathrm{cm}^{2}$ after $30 \mathrm{hrs}$ of the thermal treatment, then stays at that value until the end of the testing. The value of $R_{H}$ first increases from 0.7 $\Omega \cdot \mathrm{cm}^{2}$ to $1.8 \Omega \cdot \mathrm{cm}^{2}$ after $20 \mathrm{hrs}$ of the thermal treatment, then decreases to $0.2 \Omega \cdot \mathrm{cm}^{2}$ after 100 hrs of the thermal treatment. Additionally, the value of $\mathrm{R}_{\mathrm{L}}$ increases significantly, from 1.4 $\Omega \cdot \mathrm{cm}^{2}$ to $4.3 \Omega \cdot \mathrm{cm}^{2}$.

Fig. 3 shows that LSCF and SSCF have much smaller particle sizes than BSCF. This should contribute to higher $\mathrm{R}_{\Omega}$ for the corresponding cathodes. However, intrinsically LSCF and SSCF have higher electrical conductivities than BSCF (Section 1). Most importantly, the mismatch of TECs between BSCF and YSZ causes poor contacts (Fig. 6(b)) and thus larger resistance than 
that of the LSCF/SSCF cathode half-cell. Figs. 4(a)-(c) also shows that the low frequency polarization resistance changes of LSCF are similar to that of SSCF, but different from that of BSCF. This is consistent with the microstructure changes of the cathodes shown in Fig. 3. Some $\mathrm{SrCrO}_{4}$ particles form on the surfaces of the LSCF and the SSCF cathodes, but not on the BSCF cathode after $100 \mathrm{hrs}$ of the thermal treatment. The $\mathrm{SrCrO}_{4}$ formation hinders the oxygen adsorption and dissociation as well as its surface diffusion on the LSCF and SSCF surfaces and thus increases the low frequency resistance $R_{L}$. The smaller LSCF and SSCF particle sizes cannot compensate this adverse effect, which demonstrates the importance of preventing $\mathrm{Cr}$ poisoning from the interconnect. For the LSCF and SSCF cathodes, it seems that the overall process of $\mathrm{O}^{2-}$ incorporation and transport is easier than that in the BSCF cathode. The $\mathrm{R}_{\mathrm{H}}$ of the LSCF and SSCF cathodes is smaller than that of the BSCF cathode after the thermal treatment. This observation is inconsistent with the ionic conductivities (Section 1) and atomic radii (Section 3.1). It is possible that the dominating influence is from the $\mathrm{O}^{2-}$ incorporation in the cathodes.

The half-cells with the SDC block layers are also measured by EIS and the deconvoluted resistances are shown in Figs. 4(d)-(f).

For the LSCF cathode (Fig. 4(d)), the value of $\mathrm{R}_{\Omega}$ decreases all the time, from $1.5 \Omega \cdot \mathrm{cm}^{2}$ to $1.3 \Omega \cdot \mathrm{cm}^{2}$. Compared with the resistance of the LSCF cathode without the SDC block layer, the change trend of $R_{\Omega}$ is reversed, although the value for the sample with the SDC layer is slightly higher than that of the sample without the SDC layer. At the end of the $100 \mathrm{hr}$ thermal treatment, they are the same at $1.3 \Omega \cdot \mathrm{cm}^{2}$. The value of $R_{H}$ first increases from $0.5 \Omega \cdot \mathrm{cm}^{2}$ to $0.9 \Omega \cdot \mathrm{cm}^{2}$ after $60 \mathrm{hrs}$ of the thermal treatment, then decreases to $0.5 \Omega \cdot \mathrm{cm}^{2}$. The obvious bump of $R_{H}$ without the SDC layer shown in Fig. 4(a) from the beginning to $50 \mathrm{hrs}$ of the thermal treatment 
does not appear here. The SDC layer stabilizes the $\mathrm{O}^{2-}$ incorporation and transport process, at least near the cathode/electrolyte interface, even though it does not improve the process. Additionally, the value of $\mathrm{R}_{\mathrm{L}}$ first decreases slightly from $2.2 \Omega \cdot \mathrm{cm}^{2}$ to $2.1 \Omega \cdot \mathrm{cm}^{2}$ after $20 \mathrm{hrs}$ of the thermal treatment, then increases to $3.5 \Omega \cdot \mathrm{cm}^{2}$ after $100 \mathrm{hrs}$ of the thermal treatment, which is much smaller than that of the half-cell without the SDC layer. This means that the SDC layer is conducive to the oxygen adsorption and dissociation as well as its surface diffusion near the cathode/electrolyte interface even though such effect diminishes with the thermal treatment time.

Fig. 4(e) shows the resistance changes of the BSCF cathode. The value of $\mathrm{R}_{\Omega}$ decreases from $2.3 \Omega \cdot \mathrm{cm}^{2}$ to $1.7 \Omega \cdot \mathrm{cm}^{2}$ and the value of $\mathrm{R}_{\mathrm{H}}$ decreases from $0.6 \Omega \cdot \mathrm{cm}^{2}$ to $0.1 \Omega \cdot \mathrm{cm}^{2}$ after 100 hrs of the thermal treatment. $\mathrm{R}_{\mathrm{L}}$ increases from $1.6 \Omega \cdot \mathrm{cm}^{2}$ to $3.6 \Omega \cdot \mathrm{cm}^{2}$. Compared with Fig. 4(b), all the resistances of the half-cell with the SDC layer (Fig. 4(e)) are smaller than those of the half-cell without the SDC layer. The SDC layer effects on the ohmic resistance, cathode oxygen reduction, and ionic transport process can be explained similarly.

For the SSCF cathode shown in Fig. 4(f), the value of $\mathrm{R}_{\Omega}$ decreases from $2.4 \Omega \cdot \mathrm{cm}^{2}$ to 1.7 $\Omega \cdot \mathrm{cm}^{2}$, which is slightly smaller than that of the half-cell without the SDC layer. Also, the value of $R_{H}$ decreases slightly from $0.6 \Omega \cdot \mathrm{cm}^{2}$ to $0.4 \Omega \cdot \mathrm{cm}^{2}$, and is more stable than that of the halfcell without the SDC layer (Fig. 4(c)). There is no bump from the beginning to $40 \mathrm{hrs}$ of the thermal treatment. For the value of $\mathrm{R}_{\mathrm{L}}$, it almost linearly increases from $1.0 \Omega \cdot \mathrm{cm}^{2}$ to $2.6 \Omega \cdot \mathrm{cm}^{2}$ after $40 \mathrm{hrs}$ of the thermal treatment, then to $3.0 \Omega \cdot \mathrm{cm}^{2}$, which is smaller than that of the sample without the SDC layer. Overall, the SDC layer remains beneficial to reduce the ohmic resistance and facilitate the cathode oxygen reduction and ionic transport process.

To compare the electrochemical performance of different half cells, the polarization resistance (sum of $\mathrm{R}_{\mathrm{H}}$ and $\mathrm{R}_{\mathrm{L}}$ ) changes with the thermal treatment time are shown in Fig. 5. For 
the LSCF cathode without the SDC layer (Fig. 5(a)), the polarization resistance increases from $2.2 \Omega \cdot \mathrm{cm}^{2}$ to $4.6 \Omega \cdot \mathrm{cm}^{2}$. For the half cell with the SDC layer, it decreases from $2.8 \Omega \cdot \mathrm{cm}^{2}$ to 2.6 $\Omega \cdot \mathrm{cm}^{2}$ after $20 \mathrm{hrs}$ of the thermal treatment, then increases to $4 \Omega \cdot \mathrm{cm}^{2}$. For the BSCF cathode without the SDC layer (Fig. 5(b)), the polarization resistance fluctuates. The smallest value is 3.8 $\Omega \cdot \mathrm{cm}^{2}$ and the largest value is $5.8 \Omega \cdot \mathrm{cm}^{2}$. For the half cell with the SDC layer, it increases from $2.2 \Omega \cdot \mathrm{cm}^{2}$ to $3.8 \Omega \cdot \mathrm{cm}^{2}$, then decreases to $3.6 \Omega \cdot \mathrm{cm}^{2}$. For the SSCF cathode without the SDC layer (Fig. 5(c)), the polarization resistance increases from $2.2 \Omega \cdot \mathrm{cm}^{2}$ to $3.9 \Omega \cdot \mathrm{cm}^{2}$, then decreases to $3.7 \Omega \cdot \mathrm{cm}^{2}$, then increases to $4.5 \Omega \cdot \mathrm{cm}^{2}$. For the half cell with the SDC layer, it increases from $1.6 \Omega \cdot \mathrm{cm}^{2}$ to $3.4 \Omega \cdot \mathrm{cm}^{2}$. Overall, the polarization resistances of the half-cells with the SDC layer are smaller than that of the half-cells without the SDC layer, especially for the BSCF cathode. The introduction of the SDC block layer contributes to the oxygen reduction reaction as SDC is known as an electrocatalyst. Because SDC has a higher ionic conductivity than YSZ, the generated $\mathrm{O}^{2-}$ ions from the three phase boundaries can be quickly transferred to the electrolyte.

\subsection{Fundamental process}

The cross sections and EDS line scans of the cathode/electrolyte interface are presented in Figs. 6(a)-(c). There was no noticeable change in the microstructure of the LSCF layer except for the thin layer on the top surface next to the interconnect. The thickness of the thin layer is about $3 \mu \mathrm{m}$. Compared with the top surface shown in Fig. 3(a), the relative dense layer on the top surface consists of both large and small particles. The XRD pattern of the LSCF cathode after $100 \mathrm{hrs}$ of the thermal treatment is shown in Fig. 7. The unlabeled peaks are from the perovskite phases and consistent with the peaks in Fig. 1. The results indicate the formation of $\mathrm{SrCrO}_{4}$ 
phase with a sheet-like structure, consistent with the elemental concentration data in Table 1. The same is true for the SSCF cathode shown in Fig. 6(c). Our previous work also shows the formation of $\mathrm{SrCrO}_{4}$ phase in the $\mathrm{LSCF}$ cathode $[30,35]$. One consequence of $\mathrm{Cr}$ deposition is removal of $\mathrm{Sr}$ from the perovskite crystal structure by the formation of $\mathrm{SrCrO}_{4}$, which leads to decreases in oxygen vacancies and polarons and thus electrochemical performance. For the BSCF cathode (Fig. 6(b)), however, there is no such thin layer shown on the top surface, which is consistent with the top surface microstructure of the BSCF cathode shown in Fig. 3(b). Moreover, the XRD pattern of the BSCF cathode shown in Fig. 7 does not show $\mathrm{SrCrO}_{4}$ phase formation after $100 \mathrm{hrs}$ of the thermal treatment even though there are some impurities present. Again, in the perovskite structure, $\mathrm{Ba}^{2+}$ and $\mathrm{Sr}^{2+}$ stay in the same position. The larger ionic radius of $\mathrm{Ba}^{2+}$ can effectively prevent the extraction of $\mathrm{Sr}^{2+}$ from the perovskite structure and prohibit the formation of $\mathrm{SrCrO}_{4}$ in the BSCF cathode.

The LSCF and SSCF cathodes have good contact with the YSZ electrolyte. For the BSCF cathode, however, there is a small gap between the BSCF cathode and the YSZ electrolyte as shown in Fig. 6(b). As mentioned before, this is due to the mismatch of TECs between BSCF and YSZ, which are $20 \times 10^{-6} \mathrm{~K}^{-1}$ and $10.8 \times 10^{-6} \mathrm{~K}^{-1}$ respectively [36, 37]. For LSCF and SSCF, their TECs are about $15 \times 10^{-6} \mathrm{~K}^{-1}$ and $16 \times 10^{-6} \mathrm{~K}^{-1}$ respectively $[18,38]$, which are more comparable with that of YSZ. The poor contact of the BSCF cathode with the YSZ electrolyte is one of the reasons for the larger resistance shown in Fig. 4(b).

The cross sections and EDS line scans of the electrolyte/block layer/cathode trilayers are given in Figs. 6(d)-(f). The microstructures of the cathodes are not affected by the SDC layer. The LSCF and SSCF cathodes near the interconnect are still covered by a relatively dense thin layer while this is absent for the $\mathrm{BSCF}$ cathode, mainly because Cr-related $\mathrm{SrCrO}_{4}$ formation is a 
result of the cathode-interconnect interaction. The SDC block layer can effectively prevent the contact of the cathodes with the electrolyte and decrease the elemental diffusion between them. For the BSCF cathode shown in Fig. 6(e), no gap is found in the BSCF/SDC/YSZ structure. This means that the SDC block layer decreases the mismatch of the TECs between BSCF and YSZ. The reason is that the TEC of SDC is $\sim 12.2 \times 10^{-6} \mathrm{~K}^{-1}$, in-between those of BSCF and YSZ.

\section{Conclusions}

Three cathode materials, LSCF, BSCF, and SSCF, are compared for their electrochemical performance. The lattice constant decreases from BSCF, to LSCF, and to SSCF. The particle sizes are about $60 \mathrm{~nm}, 700 \mathrm{~nm}$, and $150 \mathrm{~nm}$ for LSCF, BSCF, and SSCF respectively. EIS results show that the SSCF cathode has the smallest polarization resistance, while the BSCF cathode has the largest polarization resistance during $100 \mathrm{hrs}$ of the thermal treatment. This mainly results from the smallest electronic conductivity for BSCF among the three materials and the large mismatch of TECs between BSCF and YSZ. The deposition of the SDC block layer can effectively prevent the contact of the cathode materials and the electrolyte, resulting in better electrochemical performance. The improvement of the electrochemical performance is most obvious for the BSCF cathode, because the SDC block layer can not only prevent the contact of the cathode and the electrolyte but also decrease the mismatch of TECs between BSCF and YSZ. SEM, EDS, and XRD results indicate $\mathrm{SrCrO}_{4}$ formation on the LSCF and SSCF cathodes next to the interconnect after $100 \mathrm{hrs}$ of thermal treatment while this is not the case for the BSCF cathode, which is directly related to the large atomic radius of $\mathrm{Ba}^{2+}$ ions. 


\section{Acknowledgements}

The authors acknowledge the financial support from Office of Naval Research under grant number ONR N00014-14-1-0466. 


\section{References}

[1] Brandon NP, Skinner S, Steele BCH. Recent advances in materials for fuel cells. Annu Rev Mater Res. 2003;33:183-213.

[2] Shao ZP, Haile SM. A high-performance cathode for the next generation of solid-oxide fuel cells. Nature. 2004;431:170-3.

[3] Zurlo F, Di Bartolomeo E, D'Epifanio A, Felice V, Sora IN, Tortora L, et al. $\mathrm{La}_{0.8} \mathrm{Sr}_{0.2} \mathrm{Fe}_{0.8} \mathrm{Cu}_{0.2} \mathrm{O}_{3-\delta}$ as "cobalt-free" cathode for $\mathrm{La}_{0.8} \mathrm{Sr}_{0.2} \mathrm{Ga}_{0.8} \mathrm{Mg}_{0.2} \mathrm{O}_{3-\delta}$ electrolyte. J Power Sources. 2014;271:187-94.

[4] Liang FL, Chen J, Jiang SP, Chi B, Pu J, Jian L. High performance solid oxide fuel cells with electrocatalytically enhanced (La,Sr) $\mathrm{MnO}_{3}$ cathodes. Electrochem Commun. 2009;11:1048-51.

[5] Jorgensen MJ, Mogensen M. Impedance of solid oxide fuel cell LSM/YSZ composite cathodes. J Electrochem Soc. 2001;148:A433-A42.

[6] Horita T, Cho DH, Wang F, Shimonosono T, Kishimoto H, Yamaji K, et al. Correlation between degradation of cathode performance and chromium concentration in $(\mathrm{La}, \mathrm{Sr}) \mathrm{MnO}_{3}$ cathode. Solid State Ionics. 2012;225:151-6.

[7] Ried P, Holtappels P, Wichser A, Ulrich A, Graule T. Synthesis and characterization of $\mathrm{La}_{0.6} \mathrm{Sr}_{0.4} \mathrm{Co}_{0.2} \mathrm{Fe}_{0.8} \mathrm{O}_{3-\delta}$ and $\mathrm{Ba}_{0.5} \mathrm{Sr}_{0.5} \mathrm{Co}_{0.8} \mathrm{Fe}_{0.2} \mathrm{O}_{3-\delta} . \mathrm{J}$ Electrochem Soc. 2008;155:B1029-B35.

[8] Jun A, Yoo S, Gwon OH, Shin J, Kim G. Thermodynamic and electrical properties of $\mathrm{Ba}_{0.5} \mathrm{Sr}_{0.5} \mathrm{Co}_{0.8} \mathrm{Fe}_{0.2} \mathrm{O}_{3-\delta}$ and $\mathrm{La}_{0.6} \mathrm{Sr}_{0.4} \mathrm{Co}_{0.2} \mathrm{Fe}_{0.8} \mathrm{O}_{3-\delta}$ for intermediate-temperature solid oxide fuel cells. Electrochim Acta. 2013;89:372-6.

[9] Ding D, Li XX, Lai SY, Gerdes K, Liu ML. Enhancing SOFC cathode performance by surface modification through infiltration. Energ Environ Sci. 2014;7:552-75. 
[10] Hsu CS, Hwang BH. Microstructure and properties of the $\mathrm{La}_{0.6} \mathrm{Sr}_{0.4} \mathrm{Co}_{0.2} \mathrm{Fe}_{0.8} \mathrm{O}_{3}$ cathodes prepared by electrostatic-assisted ultrasonic spray pyrolysis method. J Electrochem Soc. 2006;153:A1478-A83.

[11] Jiang SP. A comparison of $\mathrm{O}_{2}$ reduction reactions on porous ( $\left.\mathrm{La}, \mathrm{Sr}\right) \mathrm{MnO}_{3}$ and $(\mathrm{La}, \mathrm{Sr})(\mathrm{Co}, \mathrm{Fe}) \mathrm{O}_{3}$ electrodes. Solid State Ionics. 2002;146:1-22.

[12] Jacobson AJ. Materials for solid oxide fuel cells. Chem Mater. 2010;22:660-74.

[13] Ullmann H, Trofimenko N, Tietz F, Stover D, Ahmad-Khanlou A. Correlation between thermal expansion and oxide ion transport in mixed conducting perovskite-type oxides for SOFC cathodes. Solid State Ionics. 2000;138:79-90.

[14] Park YM, Kim JH, Kim H. In situ sinterable cathode with nanocrystalline $\mathrm{La}_{0.6} \mathrm{Sr}_{0.4} \mathrm{Co}_{0.2} \mathrm{Fe}_{0.8} \mathrm{O}_{3-\delta}$ for solid oxide fuel cells. Int J Hydrogen Energ. 2011;36:5617-23.

[15] Wei B, Lu Z, Li SY, Liu YQ, Liu KY, Su WH. Thermal and electrical properties of new cathode material $\mathrm{Ba}_{0.5} \mathrm{Sr}_{0.5} \mathrm{Co}_{0.8} \mathrm{Fe}_{0.2} \mathrm{O}_{3-\delta}$ for solid oxide fuel cells. Electrochem Solid St. 2005;8:A428-A31.

[16] Chen DJ, Shao ZP. Surface exchange and bulk diffusion properties of $\mathrm{Ba}_{0.5} \mathrm{Sr}_{0.5} \mathrm{Co}_{0.8} \mathrm{Fe}_{0.2} \mathrm{O}_{3-}$ ${ }_{\delta}$ mixed conductor. Int J Hydrogen Energ. 2011;36:6948-56.

[17] Shao ZP, Haile SM, Ahn J, Ronney PD, Zhan ZL, Barnett SA. A thermally self-sustained micro solid-oxide fuel-cell stack with high power density. Nature. 2005;435:795-8.

[18] Lv H, Wu YJ, Huang B, Zhao BY, Hu KA. Structure and electrochemical properties of $\mathrm{Sm}_{0.5} \mathrm{Sr}_{0.5} \mathrm{Co}_{1-\mathrm{x}} \mathrm{Fe}_{\mathrm{x}} \mathrm{O}_{3-\delta}$ cathodes for solid oxide fuel cells. Solid State Ionics. 2006;177:901-6.

[19] Li LP, Song J, Lu Q, Tan XY. Synthesis of nano-crystalline $\mathrm{Sm}_{0.5} \mathrm{Sr}_{0.5} \mathrm{Co}(\mathrm{Fe}) \mathrm{O}_{3-\delta}$ perovskite oxides by a microwave-assisted sol-gel combustion process. Ceram Int. 2014;40:1189-94. 
[20] Chen L, Lu CH, Zhao YZ, Ni YR, Song JB, Xu ZZ. Infrared emissivities and microwave absorption properties of perovskite $\mathrm{Sm}_{0.5} \mathrm{Sr}_{0.5} \mathrm{Co}_{1-\mathrm{x}} \mathrm{Fe}_{\mathrm{x}} \mathrm{O}_{3}(0 \leq \mathrm{x} \leq 0.5)$. J Alloy Compd. 2011;509:8756-60.

[21] Araki W, Arai Y, Malzbender J. Transitions of $\mathrm{Ba}_{0.5} \mathrm{Sr}_{0.5} \mathrm{Co}_{0.8} \mathrm{Fe}_{0.2} \mathrm{O}_{3-\delta}$ and $\mathrm{La}_{0.58} \mathrm{Sr}_{0.4} \mathrm{Co}_{0.2} \mathrm{Fe}_{0.8} \mathrm{O}_{3-\delta}$. Mater Lett. 2014;132:295-7.

[22] Shah M, Voorhees PW, Barnett SA. Time-dependent performance changes in LSCFinfiltrated SOFC cathodes: The role of nano-particle coarsening. Solid State Ionics. 2011;187:647.

[23] Jiang SP, Chen XB. Chromium deposition and poisoning of cathodes of solid oxide fuel cells - A review. Int J Hydrogen Energ. 2014;39:505-31.

[24] Liu YH, Chen J, Wang FZ, Chi B, Pu J, Jian L. Performance stability of impregnated $\mathrm{La}_{0.6} \mathrm{Sr}_{0.4} \mathrm{Co}_{0.2} \mathrm{Fe}_{0.8} \mathrm{O}_{3-\delta^{-}} \mathrm{Y}_{2} \mathrm{O}_{3}$ stabilized $\mathrm{ZrO}_{2}$ cathodes of intermediate temperature solid oxide fuel cells. Int J Hydrogen Energ. 2014;39:3404-11.

[25] Zha SW, Xia CR, Meng GY. Effect of Gd (Sm) doping on properties of ceria electrolyte for solid oxide fuel cells. J Power Sources. 2003;115:44-8.

[26] Kong X, Ding XF. Novel layered perovskite $\mathrm{SmBaCu}_{2} \mathrm{O}_{5+\delta}$ as a potential cathode for intermediate temperature solid oxide fuel cells. Int J Hydrogen Energ. 2011;36:15715-21.

[27] Asadi AA, Behrouzifar A, Iravaninia M, Mohammadi T, Pak A. Preparation and oxygen permeation of $\mathrm{La}_{0.6} \mathrm{Sr}_{0.4} \mathrm{Co}_{0.2} \mathrm{Fe}_{0.8} \mathrm{O}_{3-\delta}$ (LSCF) perovskite-type membranes: Experimental study and mathematical modeling. Ind Eng Chem Res. 2012;51:3069-80.

[28] Jin TG, Lu K. Chemical compatibility between Sr-doped lanthanum manganite air electrode and AISI 441 interconnect. Int J Hydrogen Energ. 2011;36:4440-8. 
[29] Emmerlich J, Linke BM, Music D, Schneider JM. Towards designing $\mathrm{La}_{1-\mathrm{x}} \mathrm{Sr}_{\mathrm{x}} \mathrm{Co}_{\mathrm{y}} \mathrm{Fe}_{1-\mathrm{y}} \mathrm{O}_{3-\delta}$ with enhanced phase stability: Role of the defect structure. Solid State Ionics. 2014;255:108-12. [30] $\mathrm{Li}$ WL, Lu K, Xia ZB. Interaction of $\left(\mathrm{La}_{1-\mathrm{x}} \mathrm{Sr}_{\mathrm{x}}\right)_{\mathrm{n}} \mathrm{Co}_{1-\mathrm{y}} \mathrm{Fe}_{\mathrm{y}} \mathrm{O}_{3-\delta}$ cathodes and AISI 441 interconnect for solid oxide fuel cells. J Power Sources. 2013;237:119-27.

[31] Jiang SP, Zhang S, Zhen YD. Deposition of $\mathrm{Cr}$ species at $(\mathrm{La}, \mathrm{Sr})(\mathrm{Co}, \mathrm{Fe}) \mathrm{O}_{3}$ cathodes of solid oxide fuel cells. J Electrochem Soc. 2006;153:A127-A34.

[32] Jiang SP, Zhen YD. Mechanism of Cr deposition and its application in the development of Cr-tolerant cathodes of solid oxide fuel cells. Solid State Ionics. 2008;179:1459-64.

[33] Lu K, Shen FY, Roberts R, Doucette G, McGuire M, Li WL. ( $(\mathrm{LaSr})_{\mathrm{x}} \mathrm{MnO}_{3}$ cathode stoichiometry effects on electrochemical performance in contact with AISI 441 steel interconnect. J Power Sources. 2014;268:379-87.

[34] Jiang ZY, Zhang L, Feng K, Xia CR. Nanoscale bismuth oxide im, regnated (La,Sr) $\mathrm{MnO}_{3}$ cathodes for intermediate-temperature solid oxide fuel cells. J Power Sources. 2008;185:40-8.

[35] Lu K, Shen FY. Effect of stoichiometry on $\left(\mathrm{La}_{0.6} \mathrm{Sr}_{0.4}\right)_{\times} \mathrm{Co}_{0.2} \mathrm{Fe}_{0.8} \mathrm{O}_{3}$ cathode evolution in solid oxide fuel cells. J Power Sources. 2014;267:421-9.

[36] Kim SG, Yoon SP, Nam SW, Hyun SH, Hong SA. Fabrication and characterization of a YSZ/YDC composite electrolyte by a sol-gel coating method. J Power Sources. 2002;110:222-8. [37] Zhou W, Ran R, Shao ZP. Progress in understanding and development of $\mathrm{Ba}_{0.5} \mathrm{Sr}_{0.5} \mathrm{Co}_{0.8} \mathrm{Fe}_{0.2} \mathrm{O}_{3-\delta}$-based cathodes for intermediate-temperature solid-oxide fuel cells: $\mathrm{A}$ review. J Power Sources. 2009;192:231-46.

[38] Droushiotis N, Torabi A, Othman MHD, Etsell TH, Kelsall GH. Effects of lanthanum strontium cobalt ferrite (LSCF) cathode properties on hollow fibre micro-tubular SOFC performances. J Appl Electrochem. 2012;42:517-26. 


\section{Table caption}

Table 1. Relative elemental concentrations detected from the locations shown in Figs. 3(a)-(c). 


\section{Figure captions}

Fig. 1. (a) XRD patterns of LSCF, BSCF, and SSCF particles and (b) the enlarged (110) peaks.

Fig. 2. Top surface (a) and cross section (b) of one SDC block layer on the YSZ electrolyte. The inset in (a) shows the high resolution image of the top surface.

Fig. 3. Microstructures of the cathode/interconnect interface and cathode bulks after 100 hrs of the thermal treatment: (a) (d) LSCF, (b) (e) BSCF, and (c) (f) SSCF cathodes.

Fig. 4. Ohmic, high frequency, and low frequency polarization resistance changes for (a) (d) LSCF, (b) (e) BSCF, and (c) (f) SSCF cathodes without and with the SDC block layer after different time of the thermal treatment.

Fig. 5. Polarization resistance changes of (a) LSCF cathode, (b) BSCF cathode, and (c) SSCF cathode after different time of the thermal treatment.

Fig. 6. Cross section SEM images and corresponding EDS line scan of (a) LSCF, (b) BSCF, and (c) SSCF cathodes without and with the SDC block layer after $100 \mathrm{hrs}$ of the thermal treatment.

Fig. 7. XRD patterns of LSCF, BSCF, and SSCF cathodes on the YSZ electrolyte. The unlabeled peaks are from the perovskite phases. 
Table of contents

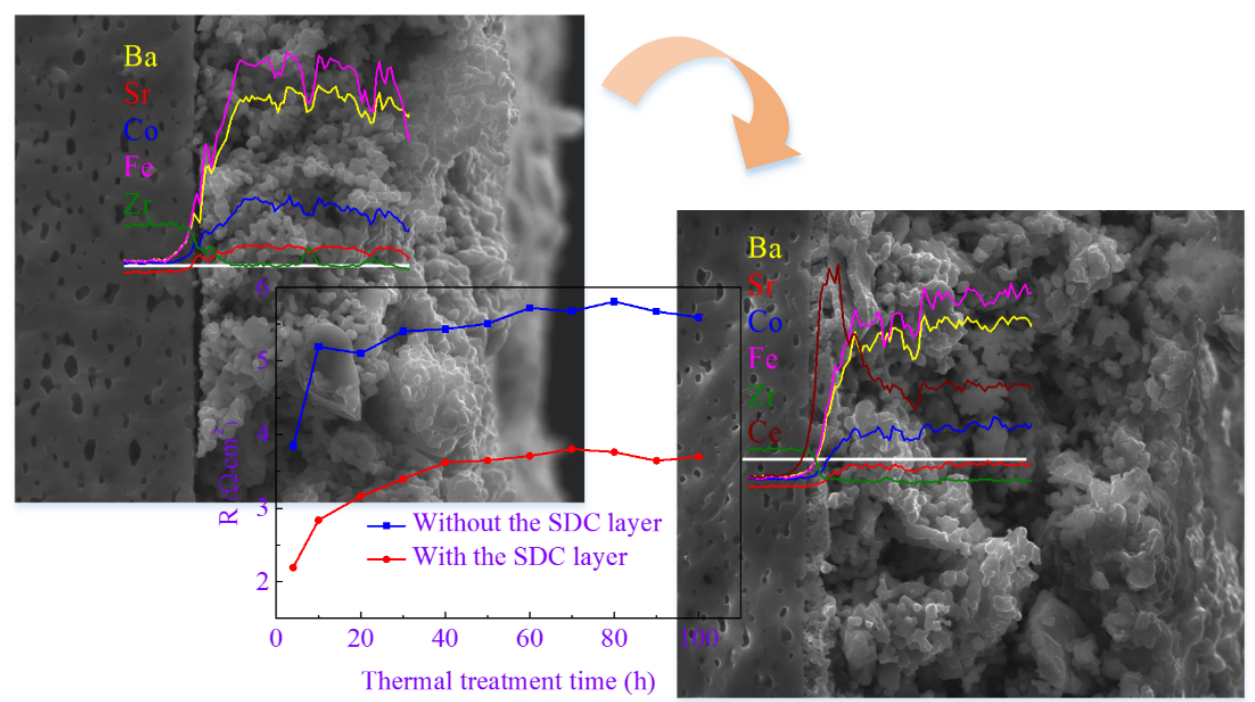


Table 1

\begin{tabular}{cccccc}
\hline \multirow{2}{*}{ No. } & \multicolumn{5}{c}{ Atomic percent (\%) } \\
\cline { 2 - 6 } & $\mathrm{La} / \mathrm{Ba} / \mathrm{Sm}$ & $\mathrm{Sr}$ & $\mathrm{Co}$ & $\mathrm{Fe}$ & $\mathrm{Cr}$ \\
\hline 1 & 22.04 & 24.48 & 7.35 & 33.40 & 12.73 \\
2 & 24.56 & 22.32 & 8.22 & 36.76 & 8.15 \\
3 & 22.42 & 23.00 & 7.51 & 36.70 & 10.37 \\
4 & 25.64 & 21.58 & 7.62 & 34.60 & 10.56 \\
5 & 17.46 & 26.98 & 6.72 & 30.31 & 18.53 \\
6 & 22.94 & 20.20 & 8.32 & 40.79 & 7.75 \\
\hline
\end{tabular}


Figure 1
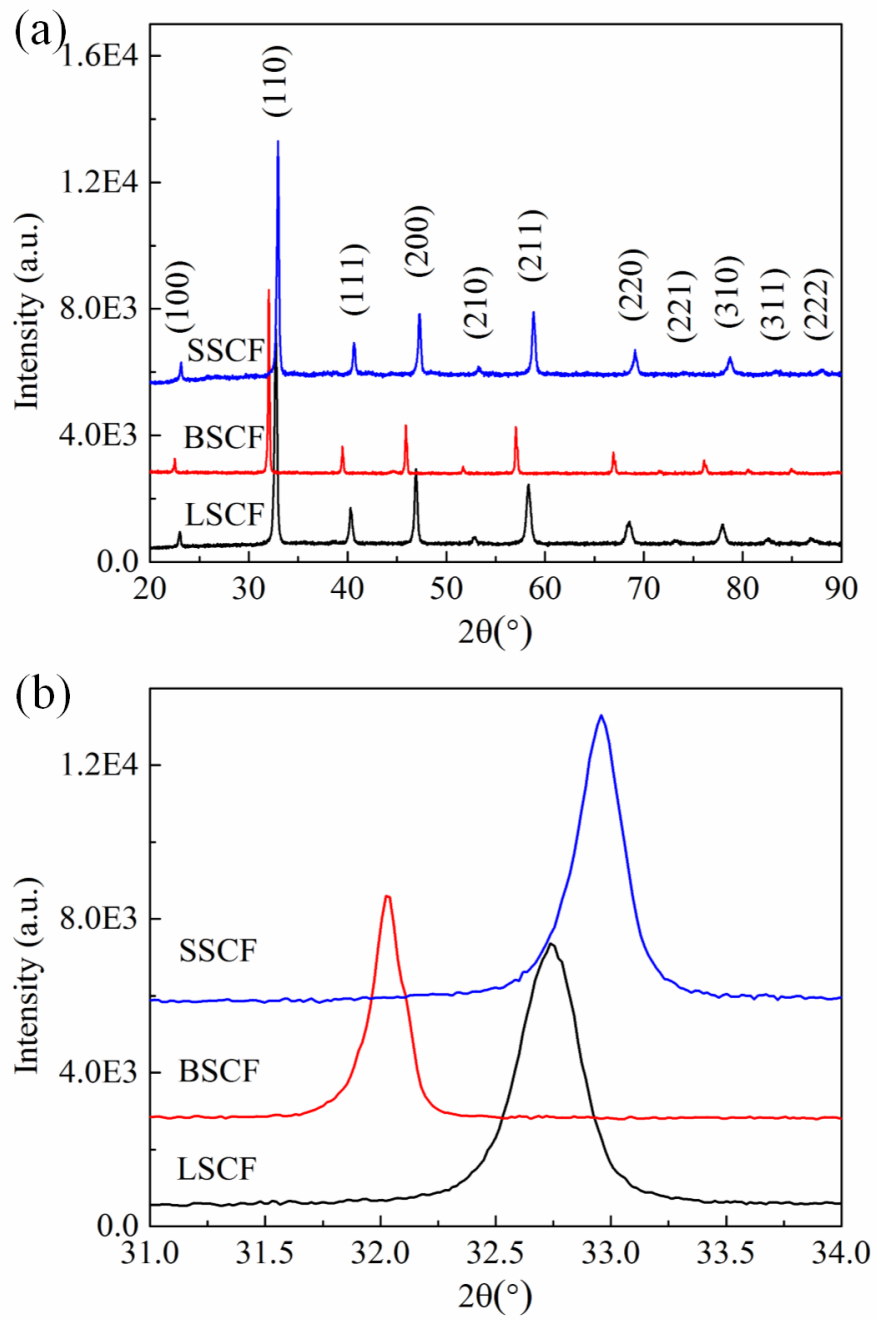
Figure 2

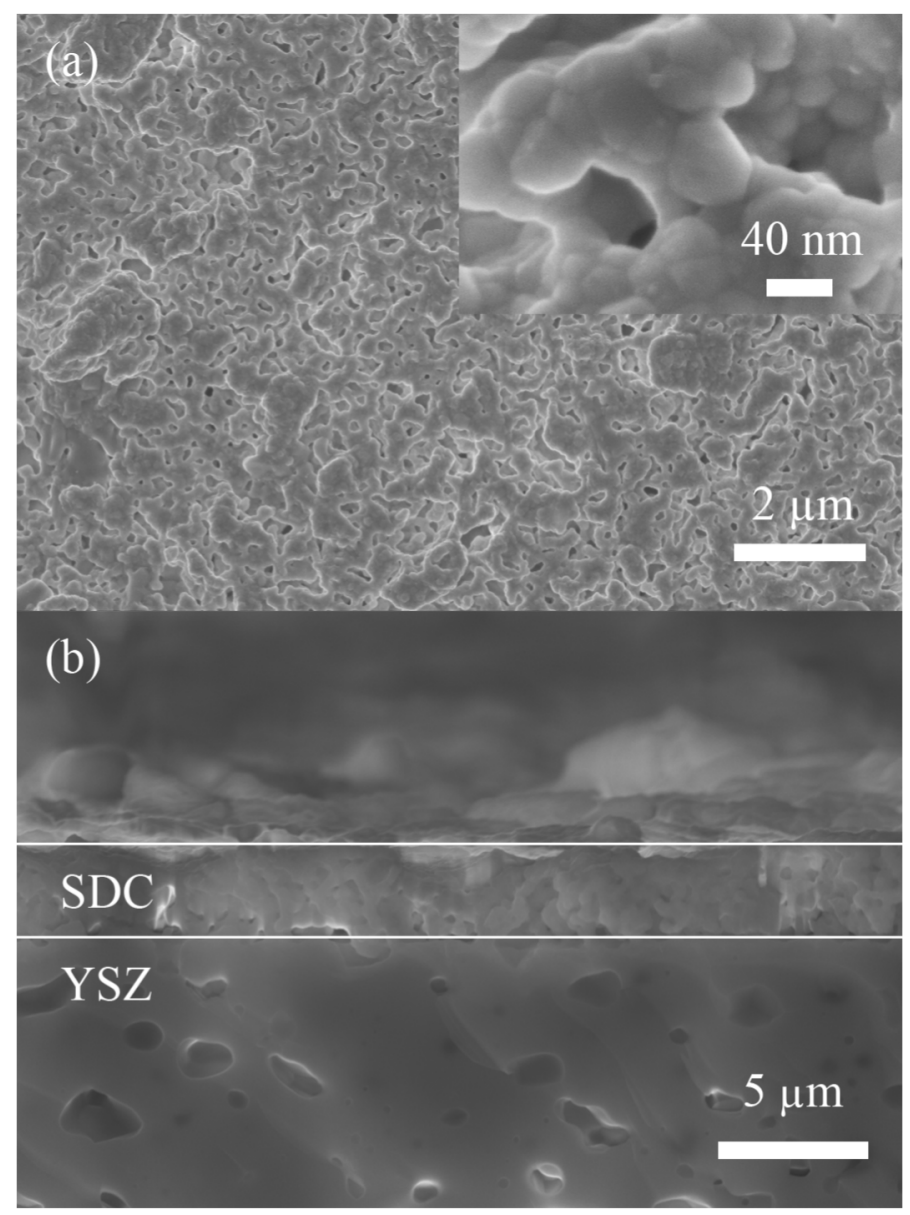


Figure 3
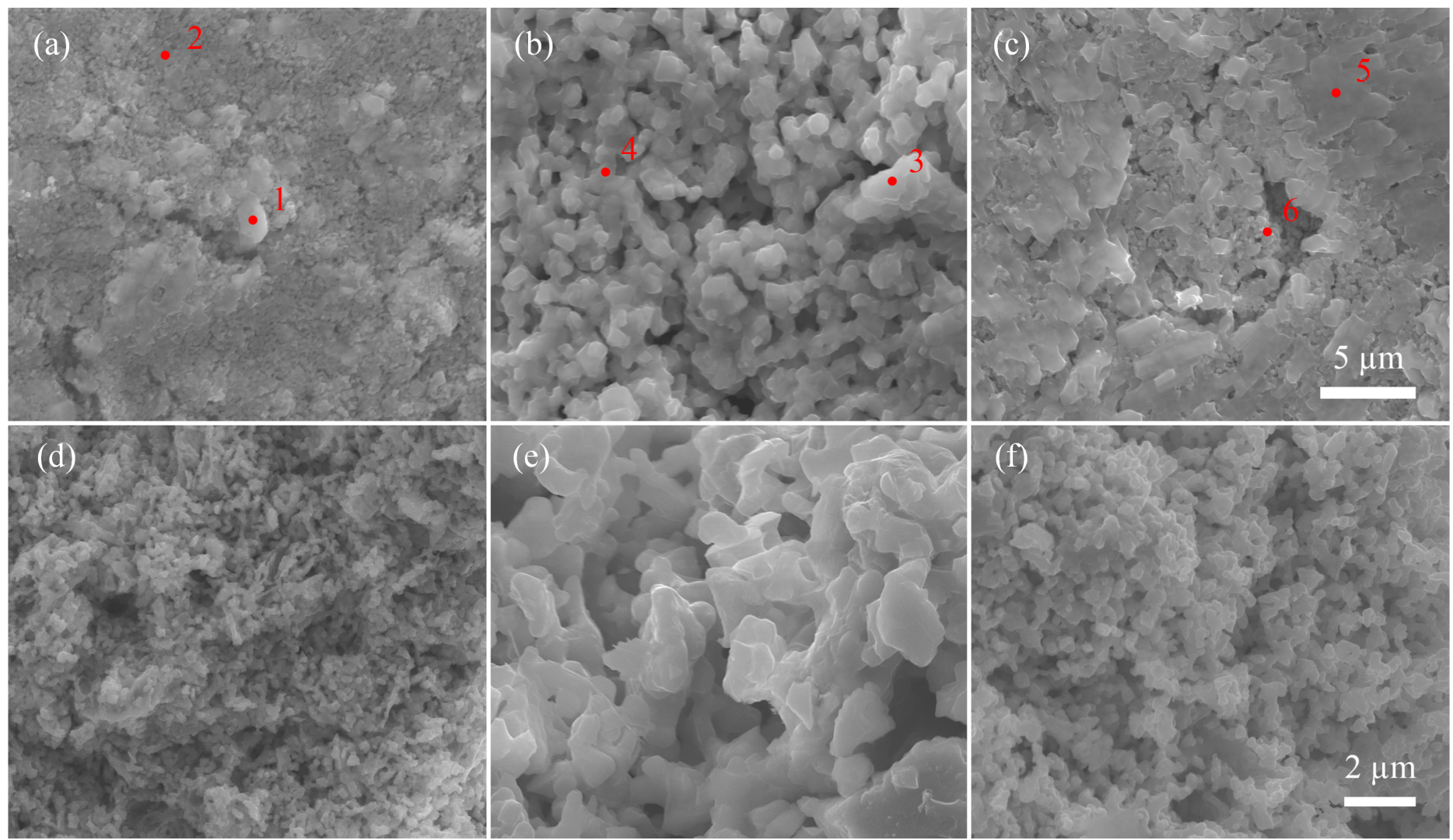
Figure 4
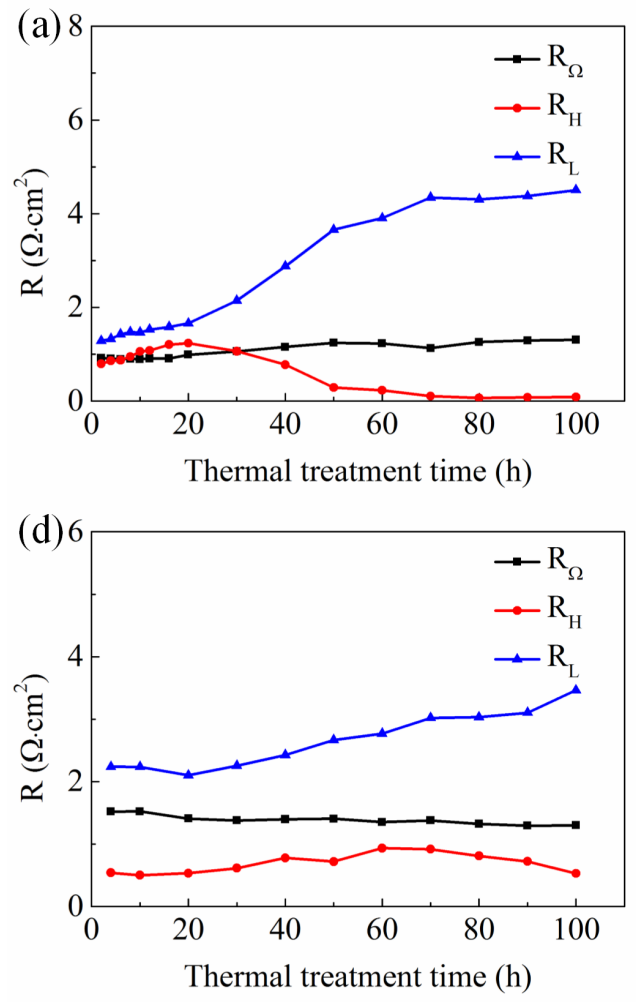
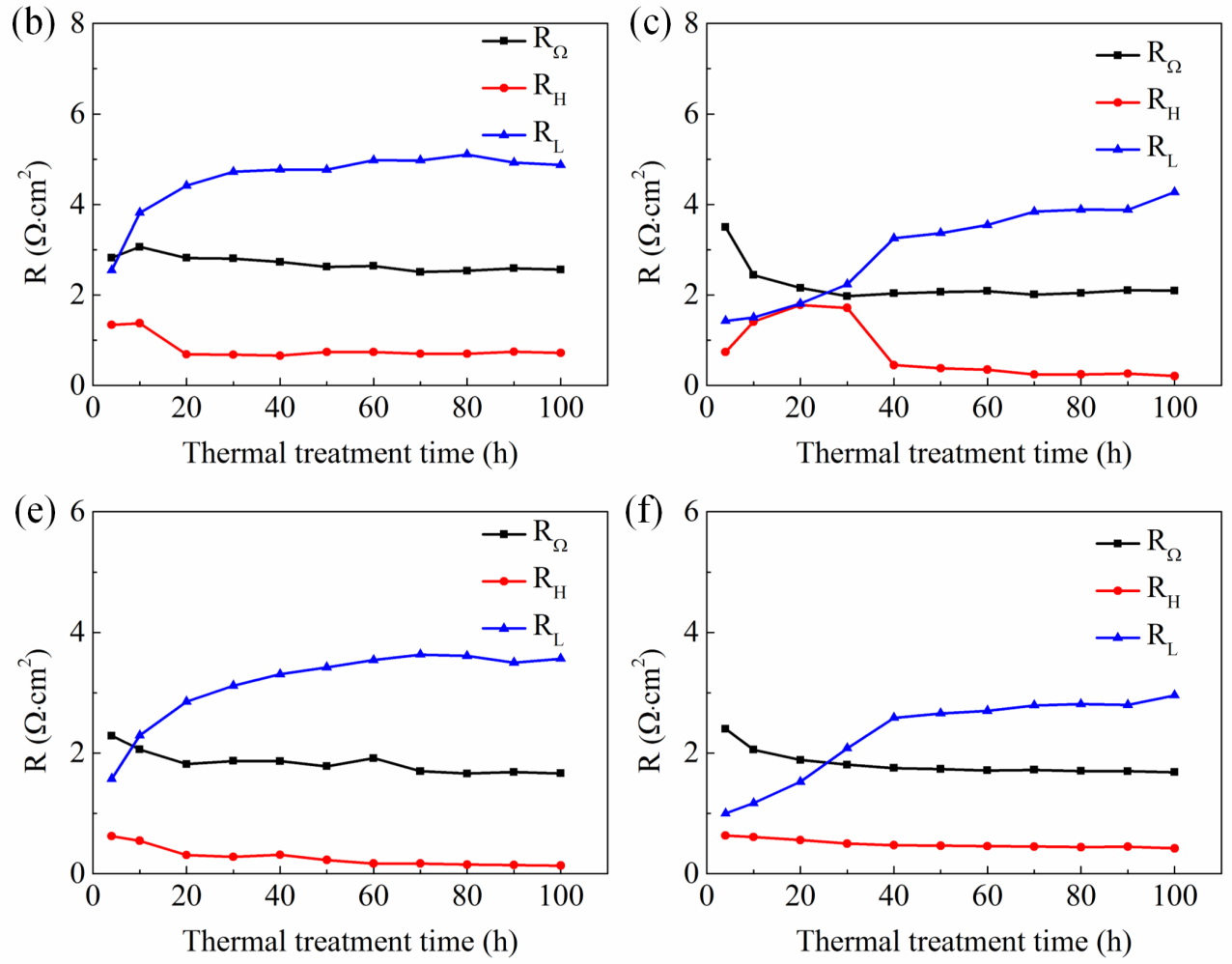


\section{Figure 5}
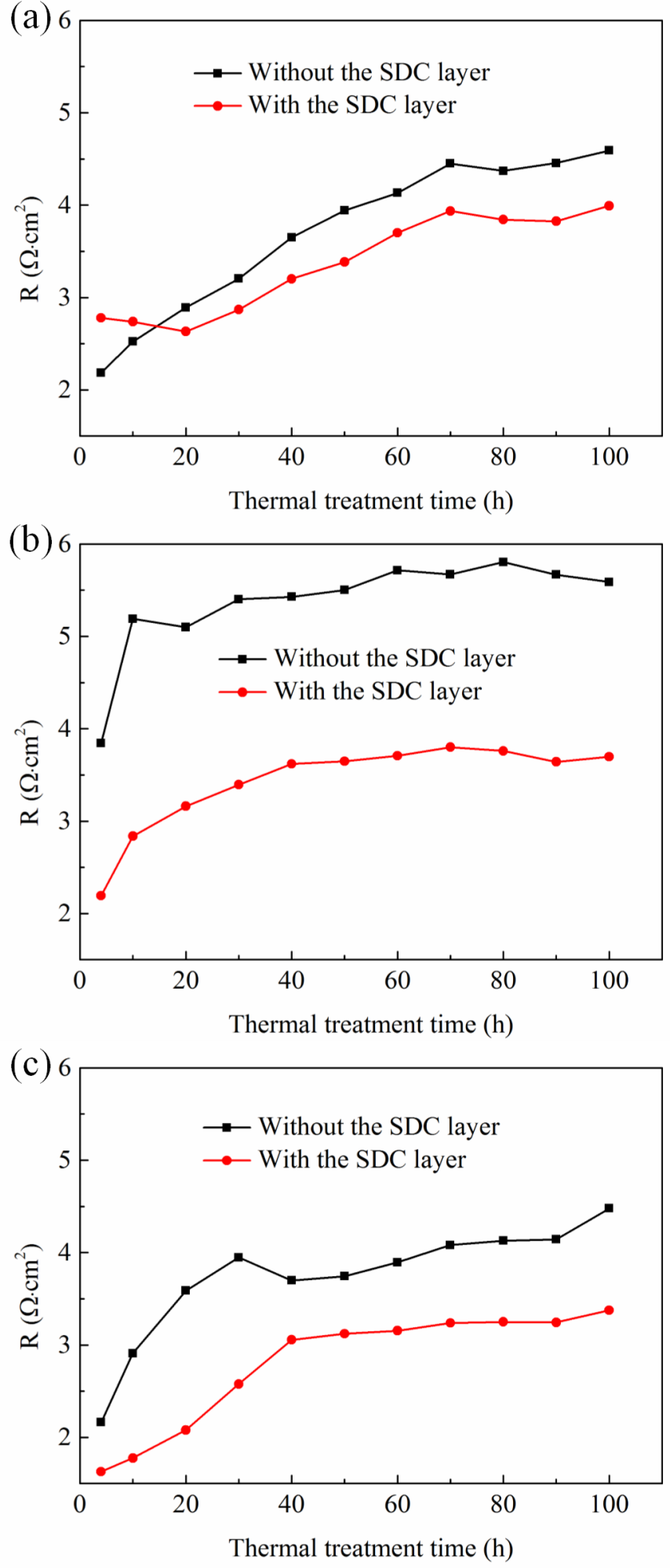
Figure 6
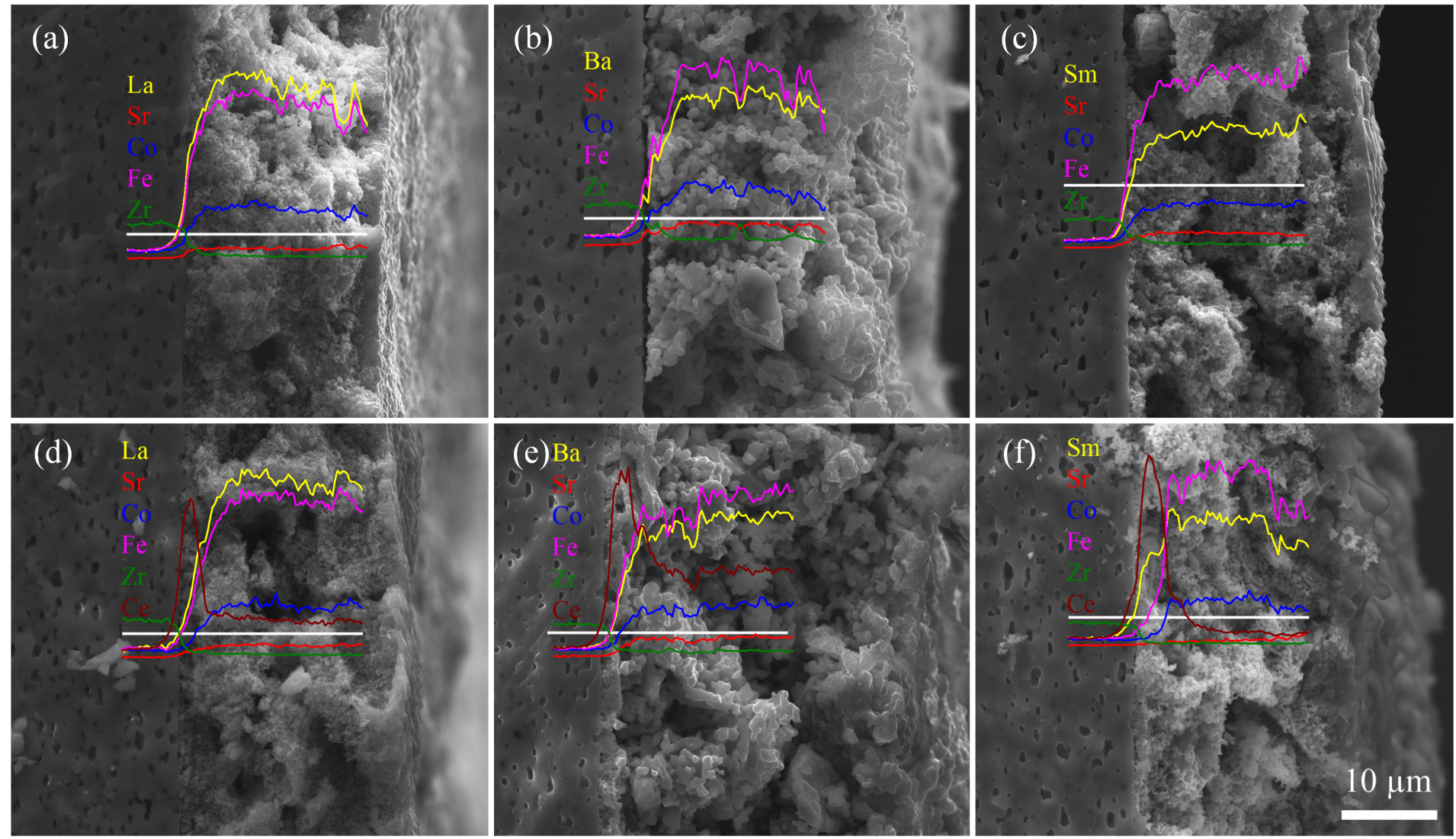
Figure 7

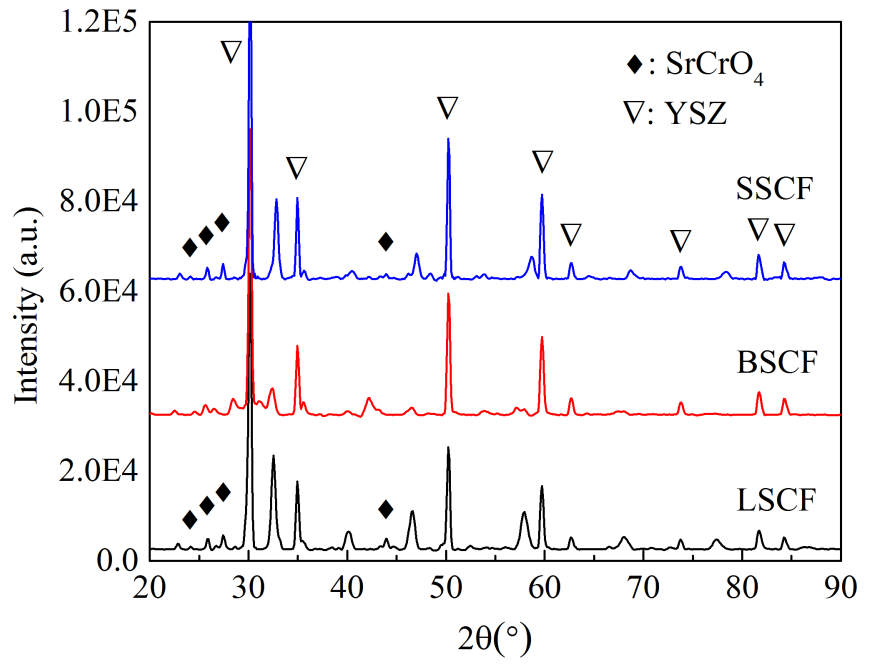

